\begin{tabular}{c} 
Volume and Issues Obtainable at Center for Sustainability Research and Consultancy \\
Journal of Business and Social Review in Emerging Economies \\
ISSN: 2519-089X (E): 2519-0326 \\
Volume 6: No. 1, March 2020 \\
CSRᄃ \\
Journal homepage: www.publishing.globalcsrc.org/jbsee \\
\hline
\end{tabular}

\title{
Identification of Institutionalized Violence in Elementary Schools
}

\section{${ }^{1}$ Khadija Sittar, ${ }^{2}$ Misbah Malik, ${ }^{3}$ Sumaira Munawar}

${ }^{1}$ Assistant Professor, Lahore Leads University, Lahore, Pakistan: khadijasittar@ gmail.com

${ }^{2}$ Lecturer, Institute of Education and Research, University of the Punjab, Lahore, Pakistan: misbahmalik@ue.edu.pk

${ }^{3}$ Assistant Professor, Lahore Leads University, Lahore, Pakistan: sumairamunawar16@gmail.com

\begin{tabular}{l}
\hline \multicolumn{1}{c}{ ARTICLE DETAILS } \\
\hline History \\
Revised format: February 2020 \\
Available Online: March 2020
\end{tabular}

Keywords

Institutionalized Violence,

Elementary Schools, Identification

\section{JEL Classification:}

A2, H70

\begin{abstract}
Violence unfolds itself in relation to the persons and activities within a specific institution, including violence from custodial authorities such as correctional officers and symbolic violence such as isolation and restriction to developmental resources. This study aims to identify the institutionalized violence prevailing in elementary schools in Punjab. Four subjects were selected at elementary level. Three male and three female elementary school teachers were selected for interview to identify the institutionalized violence. Semi structured interview protocol was used as tool of the study. Semi structured questions were developed around the following themes: inequalities in number of teaching period, discrimination in time table, demoralization, demotivation in academic activities and imposing extra duties, discrimination in leave and relaxation. The findings of the study revealed that discrimination practices of head teachers are demotivating elementary school teachers which may affect students and school performance. On the basis of findings it is recommended that training might be arranged for improving the teachers' performance.
\end{abstract}

(C) 2020 The authors, under a Creative Commons AttributionNonCommercial 4.0

Corresponding author's email address: khadijasittar@gmail.com

Recommended citation: Sittar, K., Malik, M. \& Munawar, S., (2020). Identification of Institutionalized Violence in Elementary Schools. Journal of Business and Social Review in Emerging Economies, 6(1), 69-74

DOI: $10.26710 /$ jbsee.v6i1.1027

\section{Introduction}

Violence is a very common and miserable human behaviour. Violence has been institutionalized in various forms of social activities. Traditionally the term violence suggests that injury which can be noticed apparently and physically (Turek, 2017 ). Some researchers put attention on another form of violence which is indirect and quite invisible. John Galtung (2015), one of the Norwegian peace researcher noted that some insidious form of violence also exists. A type of violence named as institutional violence is commonly used but it is a form of structural violence because it is, sometimes, abstract in nature and cannot be related to any specific institute. "Particularly the social relations have 
developed dramatically in the context of population growth and the growth of human communities." Traditionally, it is considered that institutional violence is that kind of structural violence which is formally found or simply embedded in the establishments and is well-known, or as a minimum tolerated, with the complicity of the human beings (Luft, 2016). Institutional violence is one of the subspecies of structural violence. Formal or proper violence is genuinely embedded in social institutions: officially, inside the case of a fantastic and expressed acknowledgement of such violence - as an instance, when armed forces should be trained in talents founded on counter-subversive doctrine, to apply them every time they locate it convenient; or inside the formal established order of repressive secret police corps. A true violence happens whilst, regardless of there being no formal acknowledgement, or even in the case of explicit prohibition, the institutionally cohabits with institutionalized violence (Anderson, \& Grinberg 2016).

Institutional violence has acquired huge acknowledgement in social settings, through conventional principles or facts and in instances, whilst, human beings believe this violence (In many countries, counter-subversion is a challenging subversion, or case in which have obtained social have been acknowledgement by revolutionary companies. In coming decades, important issue, what is stake for theatre, performance and performance pedagogy (Duffly, 2016).

Institutionalized violence is in contrast with personal and direct violence. The concept of the latter is that personal or direct violence is that during which the provoker may be identified. It is a type of face-to-face violence and is essential due to the fact that victim can recognize the responsible person in front of him. This is the case with crook acts, labour conflicts, bodily aggression, and so forth (Green \& Browne, 2019).

Institutionalized violence occurs to someone from and within society's systems that are fashioned, maintained, and subsequently transformed with margins of plasticity by human beings. In many instances this also consists of the sufferers, all of whom are fashioned and shaped according to the same systems (De La Cova, 2016). Institutionalized violence is different from other types of violence because it comes from the systems and not from human beings. It is not always, consequently, an instantaneous relationship from person to individual, however, as an alternative a relationship based totally upon the intermediation of the systems. In structural violence the aggressor is faceless (Duckworth, 2019).

Weiner, L. (1999)

Urban teaching: the essentials (New York, Teachers College Press).

Institutionalized violence flows within the social systems and finds out of them into interpersonal relationships. This is a totally critical difficulty for the problem of the connection among violence and lifestyle because it is a unique expression and no longer similar expressions to others. That is, structural violence is contained inside the very structures of society itself (Dubet, 2000). An incredible function of structural violence is that the victim is likewise a part of it, in a function of acquiescence or war of words. We cannot predetermine which of those positions may be taken, due to the fact this relies upon, amongst other factors, upon the diploma to which the sufferer has internalized the foremost way of life or the diploma of complaint in the direction of it that she or he has advanced (SanSegundo, Miriam, Cascales, $\underline{\text { Rosario, }}$ Bellido \& Jesus, 2018). In any case, the victim shares a few or all of the guidelines of the game to which she or he is submitted, and so the victim becomes a goal "partner" of these policies (Ayers, 2014).

Increasing and occurring diverse sorts of violence, interference of training efforts, or they rendered ineffectual considered as a space in school environment now a days. Whereas, time is another factor. Students' behaviours and living conditions are directly affected when worry and suspicion arises as an urban violence out of doors of school, mainly in the case of schools located in regions. Based on mutual admire and respect which is often demolished, school should create opportunity to construct an environment in this regard (Ayers, 2014). 
As a social trouble called intervention, in public authorities this situation considers one object of creating problems. Like mass media the agenda which guide public opinions substantially effected by them. The public and educational safety both are closer to this state of violence which is used for the purpose of declining violence in United States as precautionary measures. These inclinations showed the interruptions in legislations, administrative changes and time reflex (Garbin, 2018).

Savage (2009) and Bourdieu (2012) specified that under those instances, "the problem of violence at schools" has been highlighted for investigation, advanced in numerous fields of know-how interested by establishment of its contour and knowledge the approaches that mold its appearance.

Zaluar ( 2007) argued that under the theoretical framework of development, such class did not account for this entire situation but by using guideline approach college violence might be control. Gendering violence is also charged by the faculty which is concerned in school situations based inside the regions (Pinheiro, 2000).

In Brazil and different nations of the world, although with sole paces and characteristics in which real social inclusion is fail to introduce are based on the location in public faculties. Violence is based on the discontentment of the society (Arias, 2012). The schools who are promoting modernity inside the schools nicely mentioned that faith is a primary figure of social inclusion. Although the political and fabric symbols are continuously exhibiting fundamental creations of modernity, but many elite classes considers it fake and fictitious, in fact theses classes have a the actual and valid ownership of these social inclinations (Bourdieu, 2016).

\section{Objective of the Study}

The purpose of the study was to:

1. Identify the institutionalized violence among elementary school teachers.

2. Explore the factors that create the institutionalized violence among elementary school teachers.

3. Find out the difference of institutionalized violence between male and female teachers.

\section{Research Questions}

The following research questions were formulated:

1. What is the institutionalized violence among elementary school teachers?

2. What are the factors that create the institutionalized violence among elementary school teachers?

3. What is the difference of institutionalized violence between male and female teachers?

\section{Research Design and Procedure}

Research method and procedure was given below:

The research was qualitative in nature. The abstract perception linked with qualitative researchers is phenomenology. Population of the study was Government elementary schools of District Lahore. Purposive sampling was used for this study. Purposive sampling is commonly used in qualitative research. In purposive sampling, the research participants are selected according to the needs of the study. In those studies, researchers prefer those participants who give complete information that is suitable for the research. The sample size was 6 ESTs (male= 3, female=3) district Lahore. "The interviews were informal and open-ended, and carried out in a conversational style." Semi structured interview schedule was employed and the responses of each statement were recorded on audio tapes carefully. Themes were identified and results were converted into themes. 


\section{Results}

\section{Theme 1: Inequalities in number of teaching periods}

P1, P2 said that no there is no inequalities in number of periods. Periods are distributed equally. He argued that when time table is prepared they tried to distribute periods equally to all the teachers either they are PSTs, ESTs, and SSTs but if there would be the limited staff then they take extra lectures. Secondary School Teachers (SSTs) normally take less periods as compared to the ESEs because of their high qualification and experience. P3, P4 and P5 said that it is true that SSTs are given less periods as compared to the ESTs because of their seniority. There is no respect of ESTs if they are even PhD. There decisions are more preferable in schools. New generation is highly qualified but they are not giving preferences to utilize their knowledge.

\section{Theme 2: Discrimination in Time Table}

$\mathrm{P} 1, \mathrm{P} 2$, said that no there is no discrimination in time table. Periods are distributed with equal timings for all the teachers. He argued that when time table is prepared, they try to distribute timings equally among all the teachers either they are PSTs, ESTs, or SSTs. P3, P4 and P5 argued that timings of periods are not set according to the needs of PSTs and ESTs. Time table is prepared by the teachers and it is directed to implement it as it is. There is no permission to change the timings of periods. They try to take lectures early morning for better performance. Even they did not ask about the subject in which ESTs are expert. They are given periods after break because it is considered that being young and energetic, they can take lectures after break.

\section{Theme 3: Demoralization}

P1 said that there is no demoralization. P2 said that "Yes" ESTs are demoralized by their seniors which affects teaching methods. P3, P4 and P5 said "to some extent" they are demoralized by their seniors. PSTs and EST teachers always remain in complex even if they are highly qualified they are not given senior classes. Their knowledge and abilities are wasted. Teachers are pressurized and do not develop their personality at elementary level.

\section{Theme 4: Demotivation in Academic Activities and Assigning Extra Duties}

P1 and P5 argued that there is no demotivation in academic activities. They further argued that some extra duties are assigned by the heads but that is their duty. P2, P3, P4 said yes there is demotivation in academic activities and extra duties are assigned to PSTs and ESTs. They further argued that they are ordered by their seniors to do extra duties and they are bound to do. P5 further argued that extra duties are assigned to them.

\section{Theme 5: Discrimination in Leave and Relaxation}

P1 said that there is no discrimination in leaves and equal relaxations are given to all the teachers. P2, P3, P4 and P5 said that we are allowed two leaves in a month but we cannot take these leaves easily. If there is very important piece of work then we are allowed to take leaves and relaxations otherwise SSTs are easily take leaves and relaxations in duties.

\section{Discussion}

Majority of the teachers said that it is true that SSTs are given less periods as compared to the ESTs because of their seniority. There is no respect of ESTs if they are even PhD. Newly appointed teachers are highly qualified but they are not given preference to utilize their knowledge, whereas some of the teachers were of the view that there are not inequalities in assigning number of periods. Periods are distributed equally. He argued that when time table is prepared they tried to distribute periods equally to all the teachers either they are PSTs, ESTs, and SSTs but when there is limited staff, they take extra lectures. SSTs normally take less periods as compared to the ESTs because of their high qualification and experience.

Most of the teachers argued that timings of periods was not set after consulting with PSTs and ESTs. 
Time table is prepared by the teachers and asked to implement as it is. There is no permission to change the timings of our periods. They try to take lectures early morning for better performance. Even they did not ask about the subject in which ESTs are expert. They are given periods after break because of being young teachers who can take lectures after break. On the other side, some said that there was no discrimination in time table. Periods are distributed with equal timings for all the teachers equally.

P1 was of the opinion that there was no demoralization. P2 said that ESTs are demoralized by their seniors which affects teaching methods. P3, P4 and P5 said "to some extent" they are demoralized by their seniors. PSTs and EST teachers always remain in complex even if they are highly qualified they are not given senior classes. He is just wasting his knowledge and abilities in junior classes. Teachers are pressurized and they do not develop their personality at elementary level.

\section{Recommendations}

Following were the recommendations of the study.

1. PST and EST teachers may ask about their timings of periods in the time table. As they are highly qualified so that they might be given lectures to the senior classes as well.

2. It is recommended that allowed leaves would be given to every teacher and relaxations in duties would also be given to the PST and EST teachers.

3. PST and EST would be motivated and periods should be equally distributed in time table.

\section{References}

Anderson, G. L. \& Grinberg, J. (2016). Educational administration as a disciplinary practice: appropriating Foucault's view of power, discourse and method, Educational Administration Quarterly, 34(3), 329-353.

Arias, E.D. (2012). Faith in Our Neighbors: Networks and Social Order in Three Brazilian Favelas. Latin American Politics and Society, 46(1): 1-38.

Bourdieu, P. (2016). Habitus". In Habitus: A sense of place, Edited by: Hillier, J. and Rooksby, E. 27-34. Aldershot: Ashgate.

Dubet, F. (2000). The sociology of pupils. Journal of Education Policy 15(1): 93-104.

Duffly, C. M. T. (2016). Campus protests, casting, and institutionalized violence: the unique role of the theatre department in institutions of higher education. Theatre Survey, 3(57), 395-397

De La Cova, C. M. (2016). Patterns of trauma, recidivism, and violence in urban and institutionalized 19th-century-born African Americans and Euro-Americans. American

Journal of Physical Anthropology, 159, 126-127

Duckworth, V. (2019). Forms of institutionalized symbolic violence and resistance in the journey of a cohort of adult literacy learners. International Journal of Educational Research, 98 336-344

Green, K., Browne, K. (2019). Personality disorder traits, trauma, and risk in perpetrators of domestic violence.

Garbin, C. A. S. (2018). Hidden violence against the institutionalized elderly. Mundo Saude, 1(42), 214-229

Galtung, J. (2015). Violence, Peace, and Peace Research. Journal of Peace Research, 6(3), 167-191 Luft, A. (2016). Has the 2016 election institutionalized systemic social exclusion and violence in America-and perhaps paved the way for authoritarianism and the possible "social death" of groups perceived as undesirable to the new administration in Washington? Ewish Social Studies, 3(22), 203211.

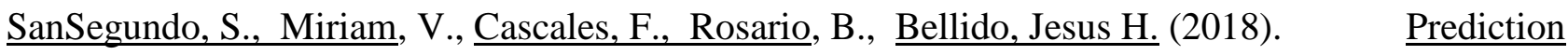
of violence, suicide behaviors and suicide ideation in a sample of institutionalized offenders with schizophrenia and other psychosis. Frontiers in Psychology, 9, 219-235.

Savage, M. 2000. Class analysis and social transformation, Buckingham: Open University Press Turek, J. (2017). Prehistoric ceremonial warfare: beginning of institutionalized violence. ArchaeologiesJournal of the World Archaeological Congress, 3 (13), 535-548. 
Pinheiro, P.S. (2000). Democratic Governance, Violence, and the rule of Law. $\quad$ Daedalus, $\quad$ 129: 119143

Zaluar, A. (2007). Unfinished Democratization: The Failure of Public Safety. Estudos Avançados, 21: $31-49$. 